\title{
A NEW NATURAL PRODUCT DIKETOPIPERAZINE, ANTIBIOTICALLY ACTIVE COMPOUND FROM SYMBIOTIC FUNGUS Purpureocillium lilacinum ISOLATED FROM MANGROVE Sonneratia alba
}

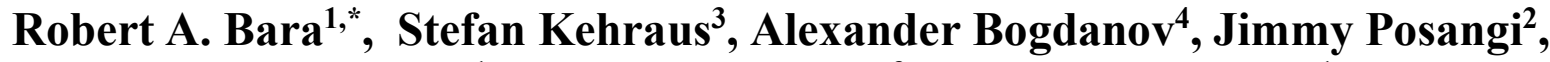 \\ Fitje Losung ${ }^{1}$, Ekaterina Egereva ${ }^{3}$, Remy Mangindaan ${ }^{1}$, \\ and Gabriele Koenig ${ }^{3}$ \\ ${ }^{1}$ Faculty of Fisheries and Marine Science, Sam Ratulangi University, Jl. Kampus Bahu, Unsrat \\ Manado 95115, Indonesia. \\ ${ }^{2}$ Faculty of Medicine, Sam Ratulangi University J1. Kampus Bahu, Unsrat Manado 95115, \\ Indonesia. \\ ${ }^{3}$ Institute of Pharmaceutical Biology, Rheinische Friedrich-Wilhelms-University, Bonn, \\ Germany. \\ ${ }^{4}$ Center for Marine Biotechnology and Biomedecine UCSD, California, the USA. \\ *E-mail: robert.bara@unsrat.ac.id
}

\begin{abstract}
We performed the study of secondary metabolites from endophytic fungus Purpureocillium lilacinum. The fungus was isolated from the Mangrove Sonneratia alba which grows in Manado Bay North Sulawesi. Chemical investigation of fractions from Biomalt agar found compounds from diketopiperazines groups namely (3S,6R)-3-(4hydroxybenzyl)-1,4-dimethyl-3,6-bis(methylthio)piperazine-2,5-dione $\quad$ (1), (3R,6S)-3-(4-hydroxybenzyl)-1,4dimethyl-3,6-bis(methylthio)piperazine-2,5-dione (2), (3S,6S)-3-(4-hydroxybenzyl)-1,4-dimethyl-3,6bis(methylthio)piperazine-2,5-dione (3) and (3S,6R)-3-(4-hydroxybenzyl)-1,4-dimethyl-3,6bis(methylthio)piperazine-2,5-dione (4), where (1) and (2) are with an additional isoprene unit linked to their aromatic chain. Hence, we can define the relative stereochemistry of all isolated compounds by analyzing the ${ }^{1} \mathrm{H}$ chemical shift differences in comparison to the available literature. We proposed that compound (1) is a new natural product due to $\beta$-SMe position in C-10. The structure of the above compounds was characterized based on consecutive spectroscopic data including NMR, UV and MS. All isolated compounds showed a narrow spectrum antibacterial activity against Gram-positive bacteria Bacillus megaterium DSM $32^{\mathrm{T}}$. So far there has been no report about the antibacterial activity of all isolated compounds
\end{abstract}

Keywords: Endophitic Fungus, Spectroscopic Analysis, Natural Products, Antibacterial Activities, Purpureocillium lilacinum, Mangrove Sonneratia alba

(C) RASĀYAN. All rights reserved

\section{INTRODUCTION}

The problem in controlling microorganisms is the increasing spread of drug-resistant microorganisms. The resistance can be due to the routine use of certain antibiotics. The discovery of new antibiotics is an essential step to keep the sustainability of effective antimicrobial medicine. Secondary metabolites proved to be interesting for drug development. In their natural habitat, these compounds are important for marine and terrestrial organisms. They play a crucial ecological role, shielding them against potential invaders, predators, other competitors or prevent diseases caused by microorganisms. Several bioactive compounds were isolated from terrestrial plants ${ }^{1,2}$ and marine animals. ${ }^{3}$ Accumulation of toxic secondary metabolites is the best strategy to fight against potential predators. These compounds show pronounced pharmacological activities and are interesting candidates for new drugs primarily in the area of cancer treatment and antibiotics. Several natural products from the marine organisms show striking structural

Rasayan J. Chem., 13(4), 2595-2602(2020)

http://dx.doi.org/10.31788/ RJC.2020.1345690

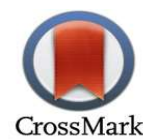


RASĀYAN J. Chem.

Vol. 13 | No. 4 |2595-2602| October - December | 2020

similarities to known metabolites of microbial origin, suggesting that microorganisms including symbiotic microorganisms are at least involved in their biosynthesis or are the true sources of these respective metabolites or host-symbiont modification. ${ }^{4-9}$ For example, Arenastatin compound derived from Dysidea sponge shares a similar structure to chryptophycin-1 which is a cyanobacterial metabolite ${ }^{10,11}$. Recently, several new bioactive products were isolated and identified with unique core structures and potent biological activities. ${ }^{3,12-14}$

As a part of our ongoing search for new bioactive secondary metabolites from terrestrial to marine endophytic fungi, we investigated Purpureocillium lilacinum that isolated from Mangrove Sonneratia alba growing in the reclamation area of Manado Bay, Manado, Indonesia. The present study represents the first investigation of natural products produced by Purpureocillium lilacinum isolated from mangrove plant Sonneratia alba.

\section{Material and Methods}

\section{EXPERIMENTAL}

The bark, leaves, and flowers of mangrove plant Sonneratia alba (Fig.-1) were collected from S. alba that growing in the reclamation area of Manado Bay, Manado, Indonesia $1^{\circ} 28^{\prime} 01.7^{\prime \prime N} 124^{\circ} 49^{\prime} 46.6^{\prime \prime E}$; Fig.-2). The symbiotic fungus was isolated from the inner tissue of the flower of the mangrove following the procedure describes below. A section apart from the flower of $S$. alba was immersed in $70 \%$ ethanol for 30 seconds and sliced under sterile conditions. The section then was positioned on the surface of malt agar in a petri dish. Chloramphenicol $200 \mathrm{mg} / \mathrm{L}$ was added to the medium to avoid bacterial contamination. Negative control was applied to cross-check the growth of epibiont fungi from external parts of the slices. The fungus started to grow from the section after 3-14 days of incubation at room temperature (Fig.-3).

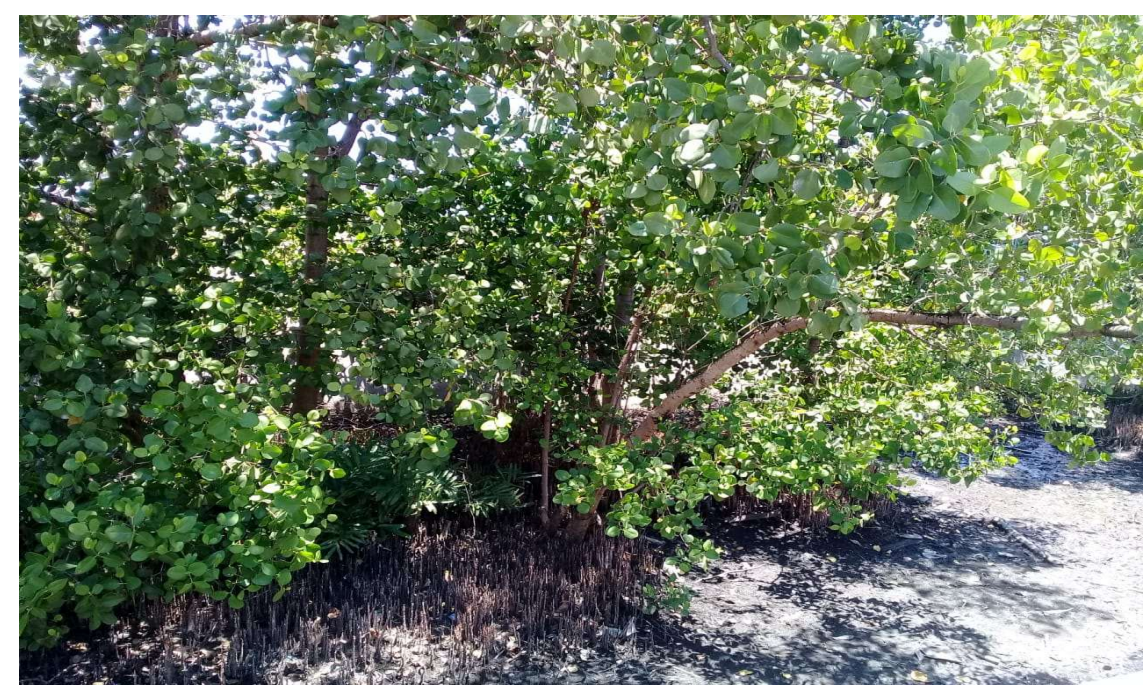

Fig.-1: Sample Sonneratia alba

\section{General Procedure}

\section{DNA Extraction}

A piece of fungal mycelium $\left(0.5 \mathrm{~cm}^{2}\right)$ was slashed from the agar dish and lyophilized in an Eppendorf (2 $\mathrm{mL})$ followed by storing in a permafrost freezer $\left(-80^{\circ} \mathrm{C}\right)$ and freeze-dryer for 2 hours and overnight respectively. Total DNA extracted with the MoBio Ultraclean DNA extraction kit (Qiagen, Hilden, Germany) from the samples. Briefly, $0.5 \mathrm{ml}$ of sodium pyrophosphate solution was added to the sample and tungsten carbide beads (Qiagen, Hilden, Germany) were added to the microtubes and cells were lysed by beating for 60s in a cell disrupter (Hybaid Ribolyser, Hybaid, Middlesex, the United Kingdom). DNA was purified according to the protocol provided by the manufacturer (Qiagen, Hilden, Germany).

\section{DNA Amplification and Sequencing}

DNA amplification by PCR was then performed using Hot StarTaq Master Mix Taq polymerase (Qiagen) and the primer pair ITS1(F) and ITS4(R) ordered from Invitrogen ${ }^{15}$ in an iCycler thermocycler. In general, 
RASĀYAN J. Chem.

Vol. 13 | No. 4 |2595-2602| October - December | 2020

thermal condition followed by 15 mins at $95{ }^{\circ} \mathrm{C}$, followed by 30 cycles of $95{ }^{\circ} \mathrm{C}$ for $1 \mathrm{~min}, 30 \mathrm{~s}$ at the annealing temperature $\left(56^{\circ} \mathrm{C}\right)$ and $72{ }^{\circ} \mathrm{C}$ for 1 min followed with the final extension $\left(72{ }^{\circ} \mathrm{C} ; 10 \mathrm{~min}\right)$. The specificity of amplicons was confirmed by running the samples on $1.0 \%$ agarose gel. The length of the amplicon was confirmed by reported articles and followed by purification of a particular band. DNA sequencing is performed to identify the fungus strain based on its genomic content. The purified amplicon was submitted for sequencing to PT. Genetika, Jakarta, followed by BLAST search against NCBI database.
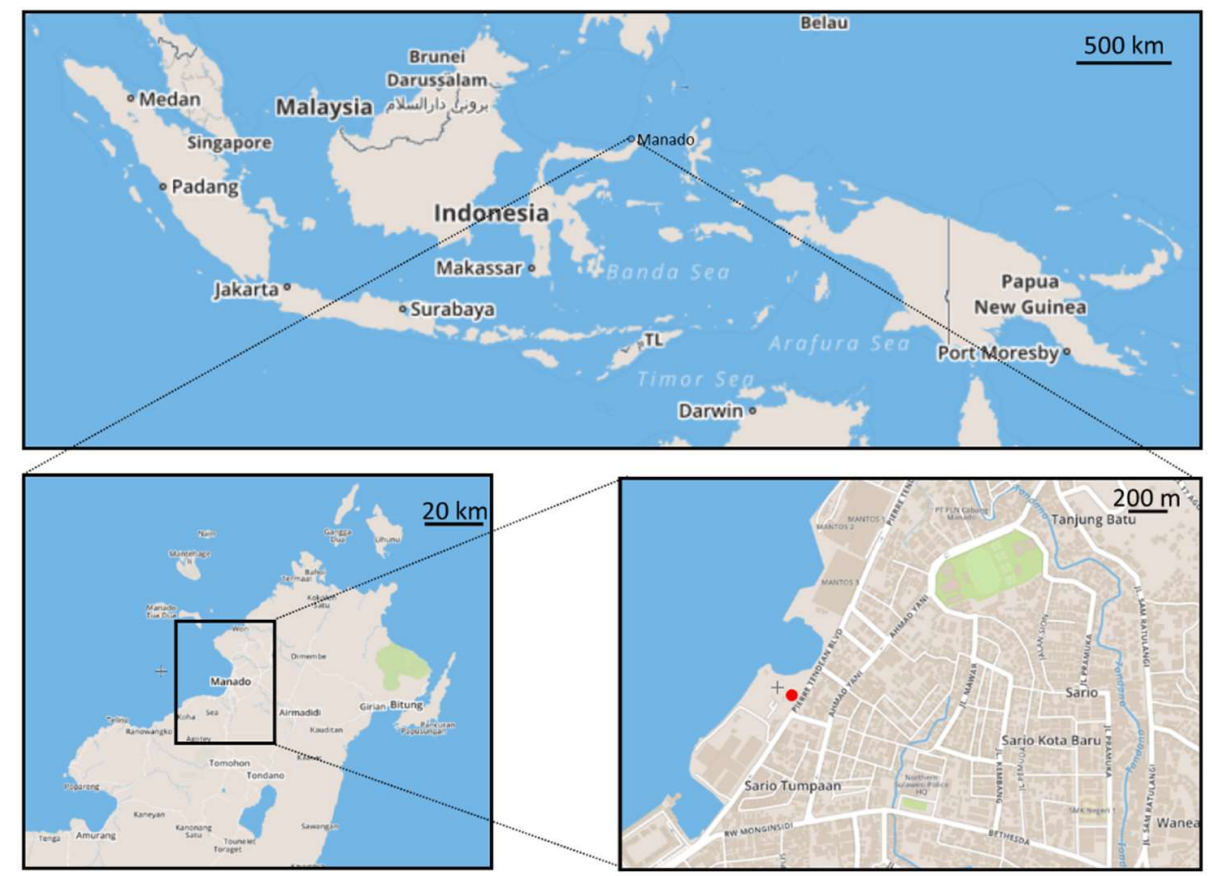

Fig.-2: Sampling site of mangrove Sonneratia alba, Manado, Indonesia. Red dot = sampling point

\section{Antibacterial Assays}

For antibacterial assays, all isolated compounds were tested their antibiotic property towards Bacillus megaterium DSM $32^{\mathrm{T}}$ and Escherichia coli DSM 498. Both isolates were originally from Deutsche Sammlung von Mikroorganismen und Zellkulturen (DSMZ), Braunschweig, Germany. The strains were refresh grown in $10 \mathrm{ml}$ slope nutrient agar in a tube at $37^{\circ} \mathrm{C}$ temperature overnight. The cultures were harvested and measured their density. The initial $\mathrm{OD}_{600}$ was set to 1 to reach the density of $8 \times 10^{8}$ cells $/ \mathrm{ml}$. The cultures were diluted until $8 \times 10^{6}$ cells $/ \mathrm{ml}$ before use, $1 \mathrm{ml}$ of the bacterial culture was subjected and seeded into the Luria Betani Agar (LB Agar) and after solidification, $20 \mu \mathrm{l}$ of the ethanolic extracts of each sample was spotted onto the plates. Chloramphenicol $(1 \mathrm{mg} / \mathrm{ml})$ and $96 \%$ ethanol served as positive and negative controls, respectively. Plates were incubated at $37^{\circ} \mathrm{C}$ for $18 \mathrm{~h}$ and checked for inhibition zones.

\section{RESULTS AND DISCUSSION}

The fungus (strain designation BG 3.13;15B.1) is kept in the authors' laboratory (RB). Furthermore, fungal culture was identified according to a molecular biological protocol by DNA amplification and sequencing of the ITS region as described previously. The BLAST search revealed a $97 \%$ similarity to Purpureocillium lilacinum (MN559614.1). The sequence data were submitted to GenBank with accession number MN689534.1.

The related fungus was statically cultivated on large scale following the method described previously ${ }^{16,17}$ (Fig). Mycelia in liquid malt cultures of $P$. lilacinum were homogenized using an automatic shaker blender and exhaustively extracted with EtOAc. The crude extract of $P$. lilacinum was subjected to Solid Phase Extraction (SPE) using C-18 column started with 25:75=methanol: water to $100 \%$ methanol to achieve 5 fractions. All fractions were submitted their bioactivity once to follow the isolation-based-activity technique. The methanol:water=75:25 of SPE fraction were further injected into HPLC with an isocratic 
RASĀYAN J. Chem.

Vol. 13 | No. 4 |2595-2602| October - December | 2020

phase of methanol:waters=8:2 to obtain compounds (1) and (2), furthermore, the methanol:water=1:1 of SPE fraction were subjected into HPLC with an isocratic phase of methanol:water $=7: 3$ to obtain compound (3) and (4) (Fig).

The structures of pure compounds of (1) to (4) were elucidated on the base of the analysis from the high resolution of ESI-MS together with 1D and 2D NMR data. The molecular formula of compound (1) and (2) were determined as $\mathrm{C}_{20} \mathrm{H}_{28} \mathrm{~N}_{2} \mathrm{O}_{3} \mathrm{~S}_{2}$ by HRESIMS (m/z $409.15749[\mathrm{M}+\mathrm{H}]^{+}$(1) and $409.1575[\mathrm{M}+\mathrm{H}]^{+}$(2) calculated for $409.57792[\mathrm{M}+\mathrm{H}]^{+}$). The differences between compounds (1) and (2) to (3) and (4) are only with the addition of isoprene unit linked to compounds (1) and (2) where there is a lack of compounds (3) and (4). The ${ }^{1} \mathrm{H}$ NMR spectra of (1) and (2) showed the presence of one aliphatic methylene H-16 resonating at $\delta_{\mathrm{H}} 3.17$ (1) and $\delta_{\mathrm{H}} 3.16(2)$, one methine $\mathrm{H}-17$ resonating at $\delta_{\mathrm{H}} 5.41$ with two aliphatic methyls resonating at $\delta_{\mathrm{H}} 1.75(\mathbf{1})$ and $\delta_{\mathrm{H}} 1.76(2)$ and $\delta_{\mathrm{H}} 1.71(\mathbf{1})$ and $\delta_{\mathrm{H}} 1.72(2)$. With a ketopiperazine group $\mathrm{H}-10$ proton resonating at $\delta_{\mathrm{H}} 4.64$ in (1) and $\delta_{\mathrm{H}} 4.47$ in (2) (Fig.-6).

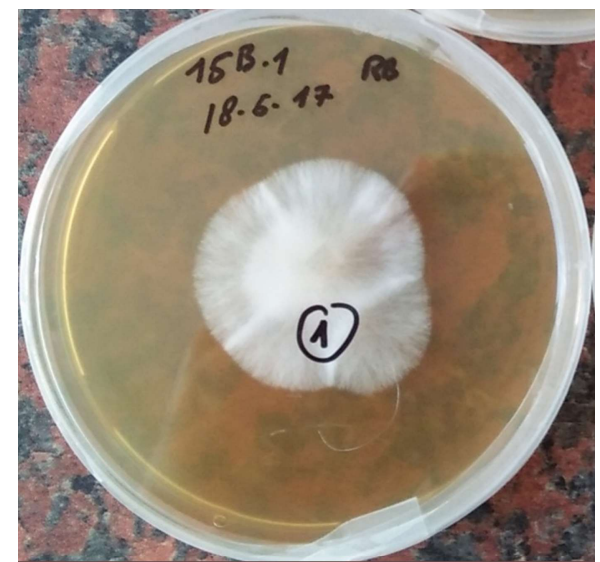

Fig.-3: Fungal Strain Purpureocillium lilacinum in Malt Agar

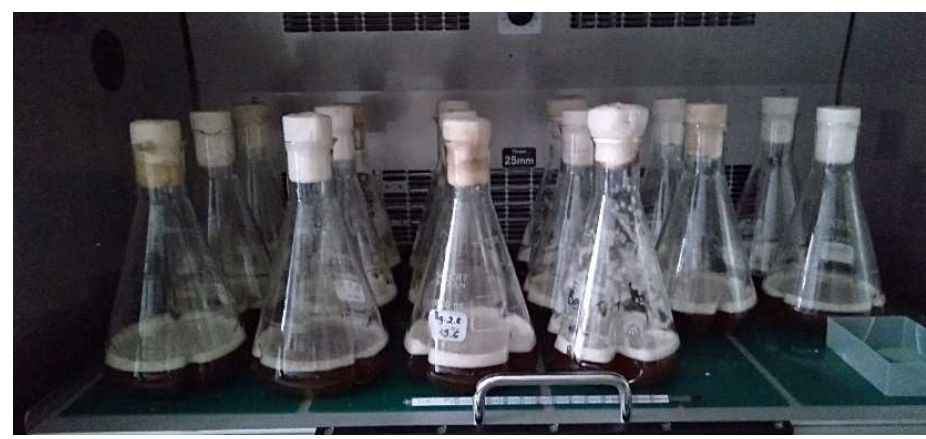

Fig.-4: Large Scale Cultures of Purpureocillium lilacinum

The difference of these resonated protons in (1) and (2) must occur due to the particular compounds have different stereochemistry in the position of $\mathrm{H}-10$ as well as S-Me proton positions. Hence, we can confirm the relative stereochemistry differences between compound (1) which was in $\beta$-SMe position and the opposite position in (2) which was $\alpha$-SMe position ${ }^{18-21}$. All the spectroscopic data were fit literature with (1) except H-10 proton position. So far, there has been no literature published elsewhere that shows the $\beta$ SMe position in C-10, proposed that compound (1) is a new natural product. Moreover, the compounds (1) was identified as (3S,6R)-3-(4-hydroxybenzyl)-1,4-dimethyl-3,6-bis(methylthio)piperazine-2,5-dione, while (2) was identified as (3R,6S)-3-(4-hydroxybenzyl)-1,4-dimethyl-3,6-bis(methylthio)piperazine-2,5dione. The important COSY and HMBC correlation of compounds (1) and (2) are presented in Fig.-7. Compound (2) previously reported from Gliocladium deliquescenes ${ }^{18}$, as well as marine sponge-derived fungus Coriolus consors. ${ }^{18,19}$ Furthermore, the related compounds were found as a mixture in Penicillium brevi-compactum (Dierckx), a fungal contaminant which antagonistic to the Dutch elm disease fungus 
RASĀYAN J. Chem.

Vol. 13 | No. 4 |2595-2602| October - December | 2020

Ceratocyctis ulmi (Buisman). ${ }^{20,}{ }^{21}$ Furthermore, the molecular formula of compound (3) and (4) were determined as $\mathrm{C}_{15} \mathrm{H}_{20} \mathrm{~N}_{2} \mathrm{O}_{3} \mathrm{~S}_{2}$ by HRESIMS $\left(\mathrm{m} / z\right.$ 341.09489 $[\mathrm{M}+\mathrm{H}]^{+}$(3) and $341.09490[\mathrm{M}+\mathrm{H}]^{+}$(4) calculated for $\left.341.09153[\mathrm{M}+\mathrm{H}]^{+}\right)$.<smiles>CC[C@]1(Cc2ccc(OCC=C(C)C)cc2)C(=O)N(C)[C@@H](CI)C(=O)N1C</smiles>

(1)<smiles>CSC[C@@]1(SC)C(=O)N(Cc2ccc(O)cc2)[C@@H](SC)C(=O)N1C</smiles>

(3)<smiles>CS[C@H]1C(=O)N(C)[C@@](Cc2ccc(OCC=C(C)C)cc2)(SC)C(=O)N1C</smiles>

(2)<smiles>CC[C@H]1C(=O)N(C)[C@@](Cc2ccc(O)cc2)(SC)C(=O)N1C</smiles>

(4)

Fig.-5: Isolated Compound from Symbiotic Fungus of Purpureocillium lilacinum

The ${ }^{1} \mathrm{H}$ NMR spectra of compounds (3) and (4) (Table-1) showed the presence of two aromatic methine protons $\mathrm{H}-1$ and $\mathrm{H}-3$ resonating at $\delta_{\mathrm{H}} 6.97$ and $\mathrm{H}-4$ and $\mathrm{H}-6$ resonating at $\delta_{\mathrm{H}} 6.66$ with $J=8.7 \mathrm{~Hz}$ indicating their meta position. These two aromatic proton signals were calibrated as two, one methylene proton $\mathrm{H}-7$ resonating at $\delta_{\mathrm{H}} 3.50 / 3.48$ and 3.13. one cyclohexane $\mathrm{H}-10$ proton resonating at $\delta_{\mathrm{H}} 4.48$ in (3) and $\delta_{\mathrm{H}} 4.64$ in (4). The difference resonated with both protons in (3) and (4) indicating both compounds have different stereochemistry in a particular position. The diketopiperazine functional group of compounds (3) and (4) also have two nitrogenic methyls resonating at $\delta_{\mathrm{H}} 3.23$ and $\delta_{\mathrm{H}} 3.02$ and two sulfonated methyls resonating at $\delta_{\mathrm{H}} 1.93$ and 1.56. the compounds (3) and (4) were identified as $(3 \mathrm{~S}, 6 \mathrm{~S}) /(3 \mathrm{~S}, 6 \mathrm{R})-3-(4-h y d r o x y b e n z y l)-$ 1,4-dimethyl-3,6-bis(methylthio)piperazine-2,5-dione, respectively.

The 2,5-Diketopiperazine (2,5-DKP) type compounds occur in numerous natural products, and this subunit is often found alone or entrenched in larger, more complex building blocks in a variety of natural products ranging from fungi, bacteria, plants, and mammals. ${ }^{22}$ They are not only a class of naturally occurring privileged structures that can bind to a wide range of receptors but they also have several features that make them attractive scaffolds for drug discovery. Due to their importance, many of this 2,5-DKP functional group are synthesized to study their ligand-bind receptors functionality. ${ }^{22-27}$

Eventually, marine resources are known for the potential novel bioactive compounds. ${ }^{3,4}$ For past decades, antimicrobial properties have been reported from different marine resources such as marine plants, animals and microbes.

The marine environment is a remarkable source for the discovery of potential antibiotics and bioactive compounds to cure several human diseases. Especially, marine-based fungi are considered as a drug source in the marine environment and being reported as a good source of antimicrobial lactones, anthracenes, and peptides. The antibacterial test of isolated compounds shows the compound (1) to (4) have a narrow 
RASĀYAN J. Chem.

Vol. 13 | No. 4 |2595-2602| October - December | 2020

spectrum antibacterial activity against Gram-positive bacteria Bacillus megaterium DSM32 ${ }^{\mathrm{T}}$. No activity array was recorded from isolated compounds against Gram-negative $E$. coli. So far, there has been no report regarding their bioactivity of all isolated compounds. Gram-negative infection control often becomes a major problem in modern medicine, this is due to the characteristics of the particular group e.g. their peptidoglycan layer which is dense and compact thereby inhibits the internalization process for antibiotics to be able to affect the cellular mechanisms within bacteria. Besides, it has an "efflux-pump mechanism", a compound removal mechanism that is not needed in their cellular biotransformation processes through their secretion system. ${ }^{28,29}$

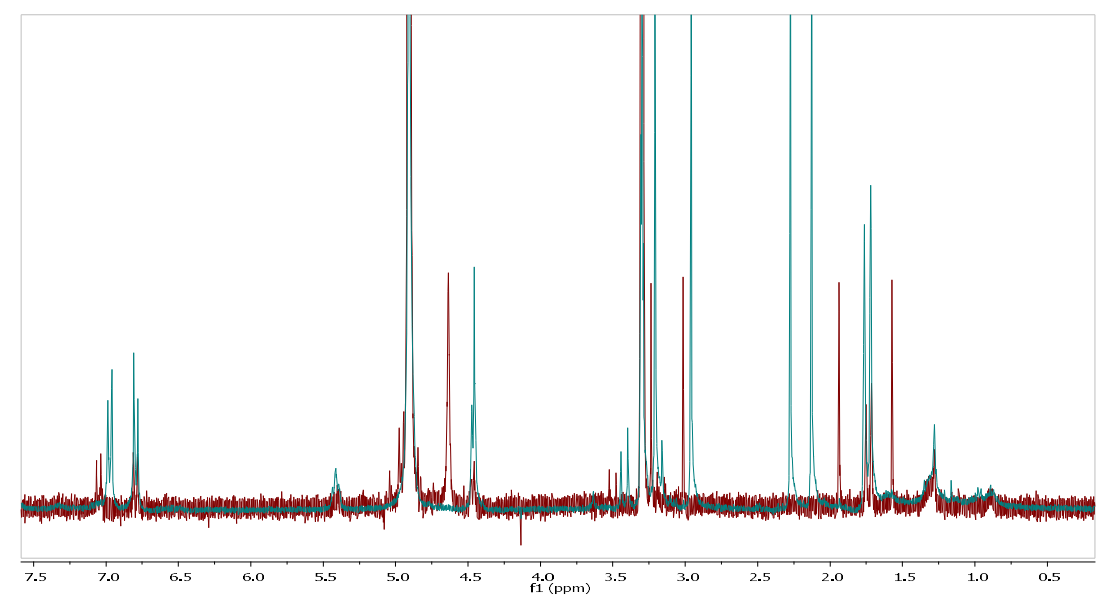

Fig.-6: Superimposed of ${ }^{1} \mathrm{H}$ NMR Spectra of Compound (1; marron) and (2; green).

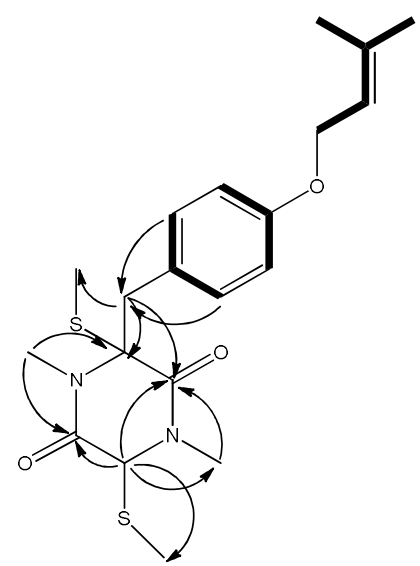

Fig.-7: Important COSY (bold line) and HMBC (arrows) Correlations of Compound (1) and (2) Table-1: ${ }^{1} \mathrm{H}$ Comparison of Isolated Compounds

\begin{tabular}{|c|c|c|c|c|c|c|c|c|c|c|c|}
\hline No. & $\delta \mathrm{c}$ & \multicolumn{2}{|c|}{$\begin{array}{c}\text { (1)MeOD d-4 } \\
\delta_{\mathrm{H}}\end{array}$} & \multicolumn{2}{|c|}{$\begin{array}{c}\text { (2)MeOD d-4 } \\
\delta_{H}\end{array}$} & \multicolumn{2}{|c|}{$\begin{array}{c}\text { (3) } \mathrm{MeOD} d-4 \\
\delta_{H}\end{array}$} & \multicolumn{2}{|c|}{$\begin{array}{c}\text { (4) } \mathrm{MeOD} \mathrm{d}-4 \\
\delta_{\mathrm{H}}\end{array}$} & \multicolumn{2}{|c|}{$\begin{array}{c}\mathrm{CDCl}_{3} \\
\delta_{\mathrm{H}}\end{array}$} \\
\hline 1,3 & 130.0 & 7.05 & $\begin{array}{c}\mathrm{d}, J=8.7 \\
2 \mathrm{H}\end{array}$ & 6.97 & $\begin{array}{c}\mathrm{d}, J=8.7, \\
2 \mathrm{H}\end{array}$ & 6.97 & $\begin{array}{c}\mathrm{d}, J=8.7, \\
2 \mathrm{H}\end{array}$ & 6.97 & $\begin{array}{l}\mathrm{d}, J=8.7, \\
2 \mathrm{H}\end{array}$ & 6.98 & $\begin{array}{l}2 \mathrm{H}, \mathrm{ABq}, \\
J=8.5 \mathrm{~Hz}\end{array}$ \\
\hline 2 & 122.5 & & & & & & & & & & \\
\hline 4,6 & 114.2 & 6.80 & $\begin{array}{c}\mathrm{d}, J=8.7 \\
2 \mathrm{H}\end{array}$ & 6.79 & $\begin{array}{c}\mathrm{d}, J=8.7, \\
2 \mathrm{H}\end{array}$ & 6.66 & $\begin{array}{c}\mathrm{d}, J=8.7, \\
2 \mathrm{H}\end{array}$ & 6.66 & $\begin{array}{l}\mathrm{d}, J=8.7, \\
2 \mathrm{H}\end{array}$ & 6.79 & $\begin{array}{l}2 \mathrm{H}, \mathrm{ABq}, \\
J=8.5 \mathrm{~Hz}\end{array}$ \\
\hline 5 & 140.1 & & & & & & & & & & \\
\hline 7 & 41.3 & 3.50 & $\begin{array}{c}\mathrm{d}, \\
J=13.6, \\
1 \mathrm{H}\end{array}$ & 3.42 & $\begin{array}{c}\mathrm{d}, \\
J=13.9, \\
1 \mathrm{H}\end{array}$ & 3.50 & $\begin{array}{c}\mathrm{d}, \\
J=14.0, \\
1 \mathrm{H}\end{array}$ & 3.48 & $\begin{array}{l}\mathrm{d}, J=14.2, \\
1 \mathrm{H}\end{array}$ & 3.53 & $\begin{array}{l}1 \mathrm{H}, \mathrm{ABq}, \\
J=14 \mathrm{~Hz}\end{array}$ \\
\hline
\end{tabular}


RASĀYAN J. Chem.

Vol. 13 | No. 4 |2595-2602| October - December | 2020

\begin{tabular}{|c|c|c|c|c|c|c|c|c|c|c|c|}
\hline & & 3.17 & $\begin{array}{c}\mathrm{d}, \\
J=13.9, \\
1 \mathrm{H}\end{array}$ & 3.18 & $\begin{array}{c}\mathrm{d}, \\
J=14.1, \\
1 \mathrm{H}\end{array}$ & \multicolumn{2}{|c|}{ Not detectable } & 3.13 & $\begin{array}{l}\mathrm{d}, \\
\mathrm{J}=14.1,1 \mathrm{H}\end{array}$ & & \\
\hline 8 & 78.0 & & & & & & & & & & \\
\hline 9 & 168.8 & & & & & & & & & & \\
\hline 10 & 64.0 & 4.64 & $\beta-\mathrm{SMe}$ & 4.47 & $\alpha-\mathrm{SMe}$ & 4.48 & $\alpha-\mathrm{SMe}$ & 4.64 & $\beta-\mathrm{SMe}$ & 4.45 & $\begin{array}{l}1 \mathrm{H} ; \alpha- \\
\mathrm{SMe}\end{array}$ \\
\hline 11 & 161.0 & & & & & & & & & & \\
\hline 12 & 28.8 & 3.24 & $\begin{array}{l}\text { s, } 3 \mathrm{H}, \\
\mathrm{NMe}\end{array}$ & 3.21 & $\begin{array}{l}\text { s, 3H, } \\
\text { NMe }\end{array}$ & 3.23 & $\begin{array}{l}(\mathrm{s}, 3 \mathrm{H}, \\
\mathrm{NMe})\end{array}$ & 3.23 & $\begin{array}{l}\text { (s, 3H, } \\
\text { NMe) }\end{array}$ & 3.20 & $\begin{array}{l}(\mathrm{s}, 3 \mathrm{H}, \\
\mathrm{NMe})\end{array}$ \\
\hline 13 & 32.3 & 3.01 & $\begin{array}{l}\text { s, 3H, } \\
\text { NMe }\end{array}$ & 2.96 & $\begin{array}{l}\mathrm{s}, 3 \mathrm{H}, \\
\mathrm{NMe}\end{array}$ & 3.02 & $\begin{array}{l}\text { (s, 3H, } \\
\mathrm{NMe})\end{array}$ & 3.02 & $\begin{array}{l}\text { (s, 3H, } \\
\text { NMe) }\end{array}$ & 2.93 & $\begin{array}{l}\text { (s, 3H, } \\
\text { NMe) }\end{array}$ \\
\hline 14 & 14.6 & 1.94 & $\begin{array}{l}\text { s, 3H, } \\
\text { SMe }\end{array}$ & 2.27 & $\begin{array}{l}\text { s, } 3 \mathrm{H}, \\
\text { SMe }\end{array}$ & 1.93 & $\begin{array}{l}\text { (s, 3H, } \\
\mathrm{SMe})\end{array}$ & 1.93 & $\begin{array}{l}\text { (s, 3H, } \\
\text { SMe) }\end{array}$ & 2.26 & $\begin{array}{l}\text { (s, 3H, } \\
\text { SMe) }\end{array}$ \\
\hline 15 & 11.7 & 1.57 & $\begin{array}{l}\mathrm{s}, 3 \mathrm{H}, \\
\mathrm{SMe}\end{array}$ & 2.13 & $\begin{array}{l}\mathrm{s}, 3 \mathrm{H}, \\
\mathrm{SMe}\end{array}$ & 1.56 & $\begin{array}{c}(\mathrm{s}, 3 \mathrm{H}, \\
\mathrm{SMe})\end{array}$ & 1.56 & $\begin{array}{l}\text { (s, 3H, } \\
\text { SMe })\end{array}$ & 2.13 & $\begin{array}{l}\text { (s, 3H, } \\
\text { SMe })\end{array}$ \\
\hline 16 & 40.0 & 3.17 & $\begin{array}{c}\mathrm{d}, \\
J=13.7, \\
2 \mathrm{H}\end{array}$ & 3.16 & brs, $2 \mathrm{H}$ & $\begin{array}{r}\mathrm{V} \\
\text { isop }\end{array}$ & thout & With & $\begin{array}{l}\text { un isoprene } \\
\text { unit }\end{array}$ & 3.04 & (brs,2H) \\
\hline 17 & 119.6 & 5.41 & $\begin{array}{c}\mathrm{t}, J=5.4 \\
1 \mathrm{H}\end{array}$ & 5.41 & $\begin{array}{c}\mathrm{t}, J=5.4, \\
1 \mathrm{H}\end{array}$ & $\begin{array}{r}\mathrm{V} \\
\text { isop } \\
\end{array}$ & thout & With & $\begin{array}{l}\text { ut isoprene } \\
\text { unit }\end{array}$ & 5.47 & $\begin{array}{l}\text { (br t, } \\
J=7 \mathrm{~Hz})\end{array}$ \\
\hline 19 & 24.0 & 1.75 & $\begin{array}{l}\text { s, 3H, } \\
\text { CMe }\end{array}$ & 1.76 & $\begin{array}{l}\text { s, 3H, } \\
\text { CMe }\end{array}$ & $\begin{array}{r}\text { U } \\
\text { isop }\end{array}$ & $\begin{array}{l}\text { thout } \\
\text { ene unit }\end{array}$ & With & $\begin{array}{l}\text { ut isoprene } \\
\text { unit }\end{array}$ & 1.77 & $\begin{array}{l}\text { s, } 3 \mathrm{H}, \\
\mathrm{CMe}\end{array}$ \\
\hline 20 & 16.2 & 1.71 & $\begin{array}{l}\mathrm{s}, 3 \mathrm{H}, \\
\mathrm{CMe}\end{array}$ & 1.72 & $\begin{array}{l}\mathrm{s}, 3 \mathrm{H}, \\
\mathrm{CMe}\end{array}$ & $\begin{array}{r}\mathrm{H} \\
\text { isop }\end{array}$ & thout ene unit $^{\text {thout }}$ & & $\begin{array}{l}\text { ut isoprene } \\
\text { unit }\end{array}$ & 1.70 & $\begin{array}{l}\text { s, } 3 \mathrm{H}, \\
\mathrm{CMe}\end{array}$ \\
\hline
\end{tabular}

\section{CONCLUSION}

1. We succeed in isolated antibiotically active fungal strain Purpureocillium lilacinum from mangrove Sonneratia alba.

2. Four diketopiperazines are isolated with the difference in their stereochemistry. Compound (1) is a new natural product based on the $\beta$-SMe position in C-10.

3. The isolated compounds show a narrow antibiotic spectrum against Bacillus megaterium. No report is published elsewhere regarding their activity against clinically isolated strains so far.

\section{ACKNOWLEDGMENT}

The authors thank Sam Ratulangi University (UNSRAT), Manado and the State of Indonesia for making this research possible. The fund from the Indonesian Ministry of Research, Technology and Higher Education through the Competitive Basic Research Fund are duly acknowledged.

\section{REFERENCES}

1. R. Hardiyanti , L. Marpaung, I.K. Adnyana, and P. Simanjuntak, Rasayan Journal of Chemistry, 12, 4 (2019), DOI:10.31788/RJC.2019.1235353

2. A. Hamad, M.G.P. Mahardika, I. Yuliani, and D. Hartanti, Rasayan Journal of Chemistry, 10, 2 (2017), DOI: 10.7324/RJC.2017.1021693

3. K.M. Fisch, C. Hertzer, N. Boehringer, Z.G. Wuisan, D. Schillo, R. Bara, F. Kaligis, H. Waegele, G.M. Koenig, and T.F. Schaeberle, Marine Drugs, 15, 12 (2017), DOI:10.3390/md15120384

4. P. Proksch, R. Edrada, and R. Ebel, Applied Microbiology and Biotechnology, 59, 2 (2002), DOI: $10.1007 / \mathrm{s} 00253-002-1006-8$

5. J. K. Stone, C.W. Bacon and J. F. White Jr., 2000, An Overview of Endophytic Microbes: Endophytism Defined, in: C.W. Bacon and J.F. White (Eds.), Microbial Endophytes, Marcel Dekker, Inc., New York, pp. 3-29, DOI:10.1201/9781482277302

6. B. Schulz and C. Boyle, 2006, What are Endophytes?, in: B. Schulz, C.Boyle and T. Sieber (Eds.), Microbial Root Endophytes, Springer-Verlag, Berlin Heidelberg, pp.1-13,DOI:10.1007/3-540-335269 
RASĀYAN J. Chem.

Vol. 13 | No. 4 |2595-2602| October - December | 2020

7. G. Strobel and B. Daisy, Microbiology and Molecular Biology Reviews, 67, 4(2003), DOI: $10.1128 / \mathrm{mmbr} \cdot 67.4 .491-502.2003$

8. G. Strobel, B. Daisy, U. Castillo, and J. Harper, Journal of Natural Products, 67, 2(2004), DOI: $10.1021 / \mathrm{np} 030397 \mathrm{v}$

9. P. Proksch, Toxicon, 32, 6 (1994), DOI:10.1016/0041-0101(94)90334-4

10. S. Eißler, T. Bogner, M. Nahrwold, and N. Sewald, Chemistry-A European Journal, 15, 42 (2009), DOI:10.1002/chem.200901750

11. M. Kobayashi, S. Aoki, N. Ohyabu, M. Kurosu, W. Wang, and I. Kitagawa, Tetrahedron Letters. 35, 43 (1994), DOI:10.1016/0040-4039(94)80024-3

12. K.L. Cheney, A. White, I.W. Mudianta, A.E. Winters, M. Quezada, R.J. Capon, E. Mollo, and M.J. Garson, PLoS ONE, 11, 1 (2016), DOI:10.1371/journal.pone.0145134

13. P. Supaphon, S. Phongpaichit, V. Rukachaisirikul, and J. Sakayaroj, PLOS ONE, 8, 8 (2013), DOI: 10.1371 /journal.pone.0072520

14. R. Bara, A.H. Aly, A. Pretsch, V. Wray, B. Wang, P. Proksch, and A. Debbab, The Journal of Antibiotics, 66, (2013), DOI:10.1038/ja.2013.28

15. T.J. White, Amplification and direct sequencing of fungal ribosomal RNA genes for phylogenetics, in PCR Protocols : a Guide to Methods and Applications. p. 315-322.(1990)

16. R. Bara, I. Zerfass, A.H. Aly, H. Goldbach-Gecke, V. Raghavan, P. Sass, A. Mandi, V. Wray, P.L. Polavarapu, A. Pretsch, W.H. Lin, T. Kurtan, A. Debbab, H. Broetz-Oesterhelt, and P. Proksch, Journal of Medicinal Chemistry, 56, 8 (2013), DOI:10.1021/jm301816a

17. R. Bara, C. Sondak, F. Losung, R.E. Mangindaan, J. Posangi, S. Kehraus, A. Bogdanov, E. Egorova, and G. Koenig, Biomedical Journal of Scientific and Technical Research, 9, 4(2018), DOI: 10.26717/BJSTR.2018.09.001834

18. J.R. Hanson and M.A. O'Leary, Journal of the Chemical Society, Perkin Transactions, 1, 0 (1981), DOI: $10.1039 / \mathrm{P} 19810000218$

19. G.-Y.-S. Wang, L.M. Abrell, A. Avelar, B.M. Borgeson, and P. Crews, Tetrahedron, 54, 26 (1998), DOI: 10.1016/S0040-4020(98)00398-6

20. W.A. Ayer, I. Altena, and L.M. Browne, Phytochemistry, 29, 5 (1990), DOI:10.1016/00319422(90)80141-3

21. L. Rahbaek, S. Sperry, J.E. Piper, and P. Crews, Journal of Natural Products, 61, 12 (1998), DOI: $10.1021 / \mathrm{np} 980230 \mathrm{f}$

22. D. Witiak and Y. Wei, Cheminform, 23, (1991), DOI:10.1021/jo00018a039

23. C. Dinsmore and D. Beshore, Tetrahedron, 58, (2002), DOI:10.1016/S0040-4020(02)00239-9

24. C. Anne, M.-C. Fournié-Zaluski, B. Roques, and F. Cornille, Tetrahedron Letters, 39, (1998), DOI: 10.1016/S0040-4039(98)02030-9

25. Y. Wei and D. Pei, Bioorganic and Medicinal Chemistry Letters, 10, 10 (2000), DOI:10.1016/S0960894X(00)00167-0

26. G. Barany and F. Albericio, Journal of the American Chemical Society, 107, 17 (1985), DOI: $10.1021 / \mathrm{ja} 00303 \mathrm{a} 019$

27. A.D. Borthwick, Chemical Reviews, 112, 7(2012), DOI:10.1021/cr200398y

28. K. Poole, Annals of Medicine, 39, 3 (2007), DOI:10.1080/07853890701195262

29. J. Posangi and R. Bara, Jurnal Pesisir dan Laut Tropis, 1, 1 (2014), DOI: 10.35800/jplt.2.1.2014.7345

[RJC-5690/2020] 